Disponível em

http://www.anpad.org.br/rac

RAC, Rio de Janeiro, v. 19, n. 5, art. 6, pp. 649-670, Set./Out. 2015

http://dx.doi.org/10.1590/1982-7849rac2015150032

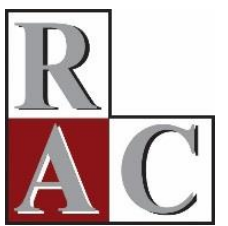

$(\mathrm{c})$ EY

\title{
Análise Sócio-hermenêutica do Discurso da Sustentabilidade a Partir de Materiais Visuais
}

Socio-hermeneutic Discourse Analysis of Sustainability Based on Visual Materials

Ana Lúcia de Araújo Lima Coelho Universidade Federal da Paraíba - UFPB

Christiane Kleinübing Godoi Universidade do Vale do Itajaí - UNIVALI

Christiano Coelho Universidade Federal da Paraíba - UFPB 


\title{
Resumo
}

Este artigo objetiva demonstrar a análise do discurso da sustentabilidade - objeto de estudo - a partir de materiais visuais. Os relatórios de sustentabilidade divulgados pela empresa estudada durante cinco anos (2007 a 2011) foram utilizados como fontes discursivas. Concluímos que o discurso da sustentabilidade dessa empresa, a partir das perspectivas metodológicas de análise de materiais visuais e dos níveis de análise sócio-hermenêutica do discurso, é uma construção carregada de interesses explícitos e, principalmente, implícitos. O estudo contribui para a exploração da potencialidade da incorporação desses materiais à análise de fenômenos organizacionais e para o estímulo do uso dessa abordagem como prática metodológica.

Palavras-chave: discurso da sustentabilidade; materiais visuais; análise sócio-hermenêutica.

\begin{abstract}
This article aims to demonstrate the discourse analysis on sustainability - the study object - based on visual materials. Sustainability reports published over the past five years (2007-2011) by the studied company were used as discursive sources. We concluded that the company's discourse on sustainability, from the methodological perspectives of visual material analysis and socio-hermeneutic levels of discourse analysis, is a construction loaded with explicit and implicit interests. The study contributes to exploring the potential of incorporating these materials in the analysis of organizational phenomena and to stimulate the use of this approach as a methodological practice.
\end{abstract}

Key words: sustainability discourse; visual materials; socio-hermeneutic analysis. 


\section{Introdução}

Comandada pela Escola Qualitativista de Madri e vinculada à Tradição Espanhola de Investigação Social Qualitativa (Alonso, 1998; Conde, 2009; Ibáñez, 1985; Ortí, 2001; Ruiz, 2009, entre outros), emergiu, no início dos anos 1970, a Análise Sociológica do Discurso (ASD), também conhecida como Análise Sócio-hermenêutica do Discurso. É nesse nível de análise que o texto é concebido de forma abrangente e vincula-se diretamente à dimensão mais pragmática da linguagem e à análise de seus usos sociais, conforme ressalta Conde (2009).

A concepção de discurso social, explica Peinado (2002), não constitui uma maneira de se referir, por meio de palavras, a uma realidade social extralinguística, mas um modo de regular o funcionamento social mediante fluxos simbólicos. O modo de pensar social está presente não apenas no ato da comunicação, mas em toda institucionalização simbólica que organiza a relação com o outro e institui representações que garantem os laços com esse outro. O caráter que tem o discurso social de ser sempre produzido em relação a outro discurso social é designado como interdiscursividade (Alonso, 1998).

No contexto organizacional, o discurso pode ser entendido como organização e produção de informação em linguagens na intenção de tornar compreensível e caracterizar "intenções, desejos, crenças e convicções, modos de ser e atuar no mundo" (Iasbeck, 2007, p. 88). O discurso organizacional configura-se, pois, como um conjunto organizado de textos e imagens que manifestam algo a respeito de quem o produz ou o emite. De acordo com Iasbeck (2009), os discursos organizacionais ganham a forma de textos - verbais, visuais, audiovisuais etc. - e têm como finalidade conquistar a confiança dos clientes e do público em geral. Especificamente, o discurso da sustentabilidade - objeto de estudo desta pesquisa, também chamado de discurso verde, ambientalista ou ecológico, propagado nas falas, documentos, folders, jornais, avisos e comunicações - constitui uma das principais estratégias discursivas da organização. Para Tinoco e Kraemer (2004), os relatórios ambientais, também denominados de socioambientais ou suplementos ambientais, são entendidos como ferramentas com as quais as empresas contam para descrever e divulgar seu desempenho ambiental.

Este artigo faz parte de um estudo mais amplo, no qual se realizou a análise da construção do discurso da sustentabilidade da empresa estudada a partir de diferentes fontes discursivas, tais como entrevistas com os atores responsáveis pela transmissão da imagem da sustentabilidade, relatórios de sustentabilidade e outras fontes midiáticas (press releases, boletins informativos e jornais de circulação nacional e regional). Aqui, no entanto, focou-se somente na análise das imagens veiculadas nos relatórios de sustentabilidade dessa empresa.

O uso de materiais visuais é observado em estudos voltados a análises e interpretações de diferentes discursos (Bohnsack, 2008; Conde \& Camas, 2001; Correa, 2008; García-Vera \& Maillo, 2011; Gordo \& Serrano, 2008; Luna Hernández, 2009; Mirzoeff, 2003; Rose, 2012; Schnaith, 1998; Serrano, 2008, 2012a, 2012b; Serrano \& Zurdo, 2012; Valle Gastaminza, 2001). A partir da compreensão dos materiais visuais vistos como discurso organizacional, do que eles são e representam, este estudo torna-se relevante na medida em que propõe uma maneira de buscar respostas a indagações, como: o que produz determinada imagem para um observador? Que elementos podem ser destacados na imagem? Que aspectos apontam a imagem? Que sentimento nos é transmitido? Que relação existe entre o texto e a imagem? O que vemos? Como se mostram os sujeitos? O que não aparece ou o que deveria aparecer na imagem? Persichetti (1997) enfatiza que a fotografia, por ser uma imagem representativa de uma realidade, pede uma abordagem crítica para que possa ser compreendida, conduzindo à reflexão e a uma possível transformação de percepção. A imagem tem o poder de informar e comunicar, enunciar e ocultar, bem como possui a capacidade de moldar e transformar o discurso e instituir-se como um poder em si mesmo.

Diante desse contexto, este artigo tem como objetivo realizar uma análise sócio-hermenêutica do discurso da sustentabilidade a partir de materiais visuais contidos nos relatórios de sustentabilidade da empresa estudada, de modo a contribuir para o desenvolvimento de metodologias de ASD no campo de estudos organizacionais. Considerando a potencialidade da incorporação de materiais visuais na análise 
de fenômenos sociais (Serrano, 2008), este estudo tem, ainda, a intenção de compreender o relatório como um discurso institucional, bem como de desmistificar o discurso da sustentabilidade e seus jargões contemporâneos.

Vinculada à tradição da abordagem de Análise Sociológica do Discurso, Serrano (2008, 2012a 2012b) desenvolveu uma metodologia de análise sócio-hermenêutica de material audiovisual, na qual estão fundamentados os procedimentos de análise e interpretação dos materiais visuais aqui realizados. Além da potencialidade da incorporação de materiais visuais na análise de fenômenos sociais no contexto organizacional mencionada anteriormente, consideramos, neste trabalho, a necessidade de estimular o uso da abordagem de ASD como prática sistemática de observação e registro dos fenômenos históricos, culturais e sociocomunicativos nas organizações. Ao analisar o discurso produzido por meio do contato real - simbólico ou imaginário dos sujeitos, seja em textos ou imagens - procuramos identificar aspectos subjacentes à organização em estudo.

A seguir, estruturam-se as seguintes seções do artigo: (a) narrativa sobre materiais visuais entendidos como texto e início da explicitação da perspectiva de análise sócio-hermenêutica dos materiais visuais; (b) delineamento metodológico da pesquisa, ressaltando o contexto da organização estudada, a fonte discursiva - relatórios de sustentabilidade - e a abordagem metodológica pertinente análise sócio-hermenêutica do discurso; (c) construção do discurso da sustentabilidade numa empresa do setor de energia elétrica; e (d) considerações finais.

\section{Imagens Entendidas como Texto: Introduzindo a Metodologia Análise Sócio- hermenêutica de Materiais Visuais}

Partindo do conceito amplo de que um documento refere-se a qualquer informação registrada num suporte, qualquer imagem pode ser considerada um documento. Dessa maneira, os enfoques que se baseiam na análise de como se manifestam as distintas particularidades da vida social por meio de objetos e de imagens, e na dimensão simbólica da cultura, vêm oferecendo novas abordagens interpretativas à investigação social qualitativa (Serrano, 2012a 2012b). A mais reveladora pesquisa de imagens visuais, segundo Rose (2012, p. 16), "não depende inteiramente da metodologia" a ser abordada, mas "do prazer, empolgação, fascinação, desejo, medo ou repulsa da pessoa olhando as imagens e então escrevendo sobre elas".

Existe uma diversidade de tipos de debates, no entender de Rose (2012), acerca das visualidades e imagens, quais sejam: filosófica, teórica e conceitual. Como formas de registro de ação e de informação, as imagens são portadoras de materialidade e de recursos de expressão distintos daqueles que caracterizaram os diferentes registros presentes na massa documental acumulada ao longo dos séculos - orientados na forma verbal, ressalta Rose (2012). Cinco aspectos referentes aos estudos da cultura visual são destacados pela autora por serem considerados relevantes no entendimento dos efeitos sociais das imagens, a saber: (a) a forma com a que as imagens explicitam ou tornam visíveis diferenças sociais; (b) a maneira como se apresentam e são vistas; (c) o entendimento do termo cultura não de forma genérica, senão a partir da análise de quem faz, de quem pode ver, da forma que pode ser visto e dos efeitos que determinado trabalho gera, a fim de garantir a discussão sobre as diferenças sociais e as relações de poder que sustentariam tais diferenças; (d) o fato de que diferentes observadores terão diferentes interpretações das imagens; e (e) o também fato de que as imagens possuem uma atuação na cultura por elas mesmas, independentemente de outras mídias, como textos e títulos que as acompanhem.

O que se pretende neste estudo é estudar a imagem social e cultural. Este propósito, no dizer de García-Vera e Maillo (2011), da força que têm a imagem ao olhar os grupos, comunidades e processos humanos derivada de uma pressuposta objetividade com que as imagens representam a sociedade. 
Para Serrano (2008), outros debates fundamentais de análise de imagens referem-se à polêmica sobre a consideração da imagem como reflexo da realidade ou como interpretação desta. De acordo com a autora, podemos encontrar três formas principais constitutivas, na moderna cultura visual ocidental, de representar a realidade. São elas: (a) a pintura (assim como o desenho, a charge ou o grafite); (b) a fotografia (seja ela estática ou dinâmica); e (c) a realidade virtual (estática ou dinâmica e, inclusive, seu formato interativo com o receptor). A primeira e a última modalidade, afirma Serrano (2008, p. 253), são "claramente representacionais e, geralmente, encontram-se fora do debate sobre sua proximidade à realidade representada", enquanto a segunda, especialmente quando da constituição da fotografia e do cinema como representações analógicas da realidade, alimenta, de modo fundamental, a controvérsia. Acerca desse debate, Mirzoeff (2003) explica que muitas imagens fazem uso de determinadas maneiras de representação, convencendo-nos de que são suficientemente verossímeis para encerrar essa desconfiança.

\section{Segundo Valle Gastaminza (2001), uma fotografia possui}

um tema, um argumento, um significado, representa algo e trata sobre algo. Uma coisa é o que aparece na imagem, o que se vê, concreto e objetivo, e outra o que a imagem sugere, aquilo sobre o que a imagem trata, abstrato e subjetivo (p. 122).

Ainda sobre a fotografia, Serrano (2008) afirma que ela nos permite enxergar a imagem retratada com detalhes concretos que poderiam passar despercebidos quando da observação direta de determinada realidade, sendo capaz de abrir a dimensão da recordação, da emoção, de nos provocar nostalgia e combinar prazer e dor, ao mesmo tempo.

Numa investigação com uso de materiais visuais ou materiais áudio-verbo-visuais (Serrano \& Zurdo, 2012), necessitamos considerar códigos que, de acordo com Schnaith (1998), mesmo inconscientemente, condicionam a existência de uma cultura audiovisual para aperceber-nos do sentido que elas proporcionam. Para a autora, há que se considerar como se vê uma cultura (códigos de percepção), como se a representa (códigos de representação) e o que se tem de conhecer num sujeito para poder ler uma imagem (códigos de conhecimento). As relações de tais códigos variam entre si, necessitando colocá-los em um contexto sócio-histórico concreto.

O estudo das imagens é assumido como uma tarefa que incita a repensar suas formas no âmbito contemporâneo. "No entorno cultural contemporâneo, tanto no âmbito da arte como nas formas de comunicação social, a relação com as imagens ocupa um lugar de centralidade" (Correa, 2008, p. 291). A imagem não difere do texto escrito somente em seu imediatismo sensorial, mas também por suscitar um efeito que não pode ser reproduzido em um texto escrito e que conecta com o emocional, afirma Mirzoeff (2003).

A obra de Rose (2012), por exemplo, ao mesmo tempo em que debate elementos da cultura audiovisual, localiza nas ciências sociais o lugar da cultura visual e, portanto, dos métodos de cultura visual, tal como aqui pretendemos trabalhar. No entender do autor, uma imagem pode ter seu próprio efeito visual (por isso é importante olhar com muito cuidado para uma imagem, alerta). Estes efeitos das formas de ver mobilizadas pela imagem são cruciais na produção e na reprodução da diferença social. Estes efeitos também produzem intersecção com o contexto social da visão e com as visualidades inerentes à visão dos seus espectadores.

Existem diferentes níveis de aproximação do material audiovisual, para os quais Rose (2012) estabelece a seguinte classificação em ordem de profundidade: (a) interpretação composicional (por vezes, neste estudo utilizada para compreender texturas, cores etc.); (b) análise do conteúdo; (c) semiologia; (d) psicanálise; (e) análise do discurso; (f) métodos etnográficos; (g) métodos de pesquisa visual. Tais níveis encontram-se melhor explicados na Figura 1. Em virtude da influência da metodologia audiovisual construída por Serrano (2008), no que tange à análise das imagens utilizadas como fontes, este estudo atravessou um ir $r$ vir na hierarquia anteriormente traçada por Rose (2012), no entanto, com ênfase na chamada Análise do Discurso II - Análise Sociológica do Discurso, abordagem a qual Serrano (2008) é vinculada. 


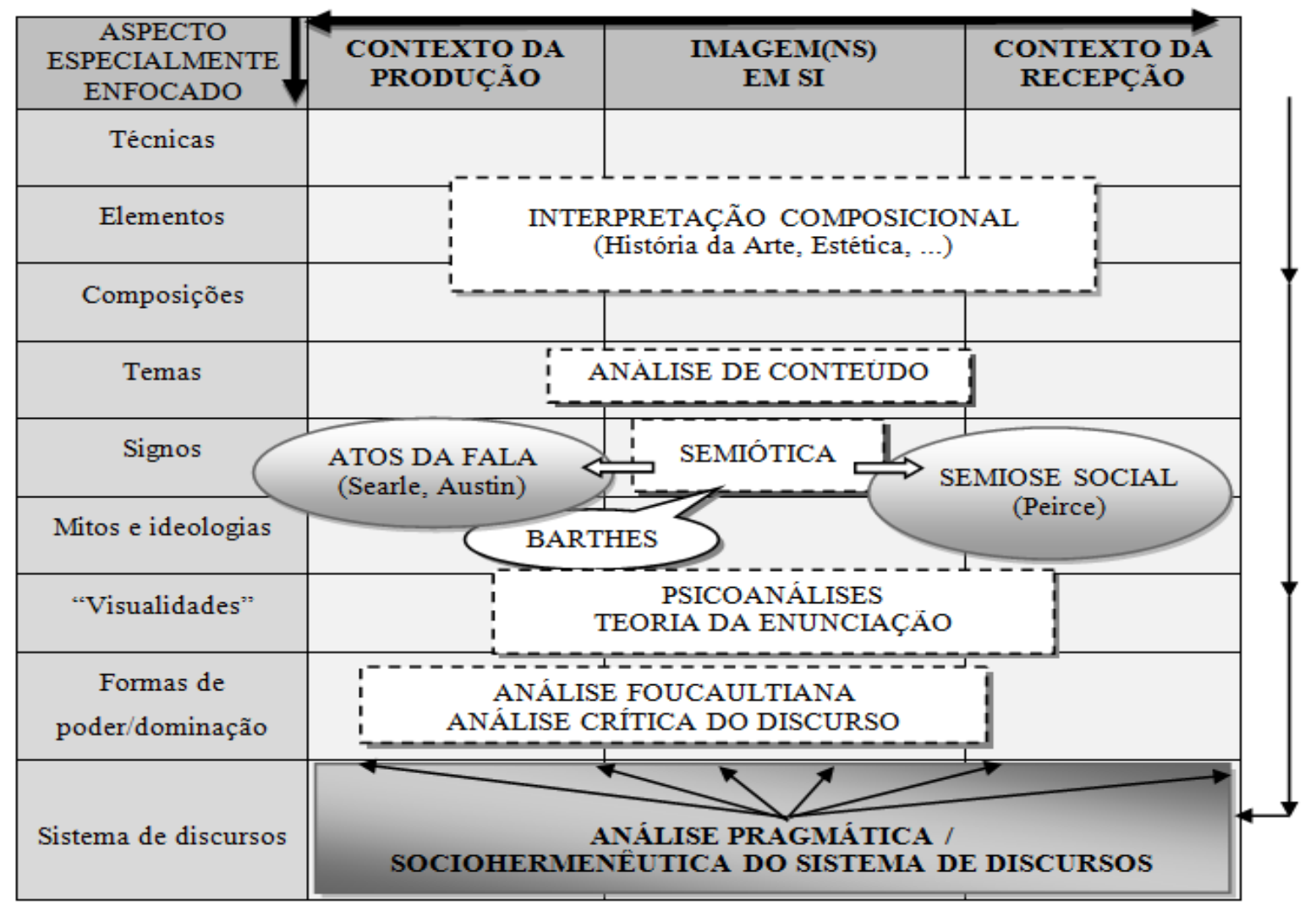

Figura 1. Perspectivas de Análise dos Materiais Visuais

Fonte: Adaptado de Serrano, A. (2008). El análisis de materiales visuales en la investigación social: el caso de la publicidad (p. 260). In A. J. Gordo \& A. Serrano (Coords.), Estrategias y prácticas cualitativas de investigación social (pp. 245-286). Madrid: Pearson Prentice Hall.

O uso de imagens na investigação social encontra-se multiplicado e diversificado, uma vez que nos situamos numa cultura visual. As sociedades contemporâneas são iconocentradas (Serrano, 2008), isto é, eminentemente centradas nas imagens e no visual. Assim, consideram-se no processo de análise como elementos iconográficos, as ilustrações que acompanham o texto, mais especificamente, no caso deste estudo, as imagens contidas nos relatórios, o que implicou em dar sentido aos códigos de representação, de saber e de percepção (Gordo \& Serrano, 2008) implícitos em uma cultura.

$\mathrm{Na}$ perspectiva de análise de material visual, adotamos, neste estudo, o percurso (Figura 1) assinalado por Serrano (2008), em virtude da vinculação da autora à Análise Sociológica do Discurso e do seu reconhecimento, na Espanha, como principal pesquisadora de análise qualitativa de material audiovisual. Com base no trabalho de Gillian Rose (2012), Serrano (2008) advoga as diferentes formas de analisar o material visual, a partir de três lugares ou níveis que centram o foco analítico: o contexto de produção da imagem, o lugar da imagem em si mesma e, por último, o contexto da recepção.

No contexto da produção da imagem, consideramos que toda representação visual é uma criação. Dessa forma, a consideração das circunstâncias de sua produção, da intencionalidade, do processo de ordem e criação, de sua difusão e do contexto no qual foi produzida, contribuiu para compreender o efeito que cada imagem possuía. De acordo com Serrano (2008), toda imagem se produz num contexto social concreto que implica uma série de relações econômicas, sociais e políticas, institucionais e práticas que a rodeiam. No segundo nível de análise, entendido como o lugar da imagem em si, consideramos a imagem como produto de um conjunto relevante de decisões, necessitando, para isso, atentarmos para: a organização espacial da perspectiva que está sendo estimulada; os elementos, signos e símbolos utilizados; o lugar onde se situa o foco; o tipo de enquadramento; o ritmo das sequências das imagens; objetos, formas e cores mais vistosos; os recursos utilizados; os personagens, relações e contextos exibidos; como se apresentam; e, ainda, para os aspectos que não estão explícitos: o tipo de relações que naturalizam; a visão de mundo envolvida; além dos recursos que os tornam possível. Nessa 
análise, levamos em consideração o gênero em que se encontra a imagem, que a condiciona e que gera expectativas diversas (drama, ficção científica, publicidade, documentários, materiais educativos etc.).

O nível do contexto da recepção, ou melhor, âmbito, momento, lugar, identidade, posição, expectativas e interesses (Serrano, 2008) são considerados desde que a imagem é percebida por diferentes públicos, até mesmo nos contextos sócio-históricos em que essa recepção acontece. De maneira sintética, destaca Serrano (2012b), buscamos a representatividade estrutural na análise sóciohermenêutica, no intuito de saturar os principais lugares de emissão e recepção das imagens, ver diferenças, conflitos ou alternativas possíveis. Quando se trata de seleção de imagens, o que importa é selecionar textos visuais, buscando discursos através da localização das posições diversas (inseridas nas relações de conflito e contradição) de emissão e recepção dos ditos textos com imagens (Serrano, 2008). A busca de uma representatividade estrutural deve expressar uma maioria de modalidades de emissão e recepção de mensagens, para saturação dos lugares de investigação, segundo Ibáñez (1979). Para esse autor, trata-se de saturar a estrutura (lugares da enunciação e recepção dos discursos), de mostrar relações e não indivíduos.

Procuramos responder por meio desses níveis as indagações apresentadas inicialmente e outros questionamentos. Para tal, foi preciso considerar alguns aspectos, destacados por Serrano (2008), no momento de analisar o visual e integrá-lo em contextos mais amplos, como é o caso dos(as): (a) técnicas - ao criar e visualizar uma imagem, o uso de determinada tecnologia condiciona intensamente sua forma, significado e efeito (pictóricas, fotográficas, cinematográficas, de animação etc.); (b) elementos envolvem personagens, artefatos, lugares ou relações que se mostram nas imagens; (c) composições dizem respeito à forma de apresentar uma imagem (cores, enfoques, luminosidades, formas de combinação, de saturação, de chamar atenção, enquadramento, ponto de vista, ritmo etc.); (d) temas são construções analíticas que fazem referência ao conteúdo explícito e manifesto das imagens, que geralmente se apresentam agrupadas em categorias temáticas, conjunto de elementos, bem como nas relações explícitas entre elas; (e) signos - entendidos por combinações de significantes e significados, que atendem às suas diversas tipologias: signos icônicos (figurativos, imitativos), plásticos (cores, formas, texturas, composições) e linguísticos, símbolos, indícios etc.; (f) mitos e ideologias - referemse à articulação de signos em sistemas significativos que revelam as estruturas fundamentais do social, buscando signos e códigos dentro do texto que ocultam o social; (g) visualidades - incluem as maneiras de ver, resultantes de processos sociais e individuais complexos, desde o enfoque psicanalítico. A partir desta etapa, centramo-nos nos efeitos emocionais das imagens visuais e em seu impacto na geração de diferentes tipos de subjetividade, independentemente de seu significado concreto; (h) formas de poder/dominação - consideramos os contextos político e econômico do uso das imagens e o acesso desigual aos recursos que se mobilizam, evidenciando como funciona o poder e como as próprias imagens reproduzem e geram formas de desigualdade e exclusão social; (i) sistemas de discursos articulada à Análise Sócio-hermenêutica e Pragmática (Alonso, 1998), envolve a inserção de imagens em discursos que, por sua vez, são somente compreensíveis em seu relacionamento em determinados contextos (de produção e de recepção), e que estabelecem entre si relações complexas de implicação, subordinação, hegemonia e/ou de conflito.

Serrano (2008) considera que as imagens são textos em si mesmos, ou partes de textos, aos quais atribuímos características que os tornam distantes de outros textos exclusivamente linguísticos. A diferença fundamental encontra-se sintetizada em ditos populares, como exemplifica Serrano (2008, p. 251): “'uma imagem vale mais que mil palavras' ou 'o que os olhos não veem, o coração não sente", 'ver para crer', ou, em um sentido muito distinto, 'mostrada a imagem, perdida a magia'."

Por fim, do que se tratou de delimitar quanto ao método de análise do material texto-audio-visual neste estudo foi tecer uma possibilidade de integração entre a Análise Sociológica do Discurso (Conde, 2009; Serrano, 2008) e a Análise Sócio-Hermenêutica e Pragmática construída por Serrano (2008). 


\section{Delineamento Metodológico da Pesquisa}

\section{O contexto da organização estudada}

A reforma do setor elétrico brasileiro, ocorrida a partir dos anos 1990, teve uma característica em destaque que foi a separação dos três segmentos de atuação: geração, transmissão e distribuição, além do aumento de consumo pelas diversas classes sociais. Para que um aproveitamento numa hidrelétrica seja considerado sustentável, os empreendimentos seguem critérios de sustentabilidade, deixando transparecer uma análise sobre os aspectos sociais, culturais, ecológicos, ambientais, territoriais, econômicos e políticos. Atualmente, o setor elétrico, dado o grande número de rios e bacias que o país possui, é constituído por um número representativo de usinas, que geram a maior parte (cerca de $80 \%$ ) da energia brasileira, afirmam Morch, Correia, Leite, Bueno e Cogan (2009).

Assim, no intuito de ampliar a compreensão da realidade em diferentes contextos no que tange ao discurso da sustentabilidade, a empresa escolhida neste estudo foi uma do setor elétrico de geração e distribuição de energia na Região Sul do Brasil - a Tractebel Energia S. A. Com sede em Santa Catarina, a empresa é uma produtora independente de energia e líder do setor privado de geração de energia elétrica do país. A Tractebel atende as principais concessionárias de distribuição de energia brasileiras e mantém significativa carteira de clientes industriais. É uma empresa de capital aberto e está listada no Novo Mercado de Bolsa de Valores de São Paulo. Com um parque gerador composto por hidrelétricas e usinas termelétricas, a empresa está presente em doze estados, abrangendo as cinco regiões brasileiras. Fortemente regulamentado, esse é um setor estratégico no que se refere ao desenvolvimento econômico brasileiro, todavia provoca alterações no meio ambiente de maneira significativa, sendo considerada uma atividade de médio impacto, segundo a Lei n. ${ }^{\circ} 10.165$ (2000).

\section{Fonte discursiva do estudo: relatórios de sustentabilidade entendidos como texto e imagem}

Os discursos organizacionais são revelados em diferentes atos comunicativos, cunhados por Halliday (2009) como atos retóricos, recebendo tal denominação por serem construídos para influenciar as percepções do público. Entre eles, exemplificam-se como atos retóricos organizacionais as declarações de objetivos e missão, memorandos, mensagens de propaganda, relatórios anuais, comunicados à mídia (press releases), entrevistas de porta-vozes, videoclipes, sites institucionais, documentários, notas de esclarecimento, solidariedade ou protesto, manifestos, cartas ou mesmo eventos por meio de palavras e outros símbolos, esclarece Halliday (2009). Trata-se, então, de todo discurso que se torna uma retórica ao tentar persuadir, convencer, guiar ações, influenciando as relações humanas (Halliday, 2009). Para conquistar a confiança de seus clientes e população, as empresas, geralmente

exageram na explicitação de seus propósitos, evitando que, dessa forma, o leitor possa participar de modo ativo de sua interpretação, desestimulando a interação; por outro lado, textos mais sutis instigam o destinatário a descobrir novos significados, podendo tornar-se perigosos (no caso de proporcionarem ambiguidades indesejáveis) ou altamente atraentes, por evocarem a participação, captando a atenção e o interesse do público (Iasbeck, 2009, p. 22).

Os discursos sobre sustentabilidade proferidos por empresas procuram vincular práticas gerenciais ambientais, sociais e econômicas a uma imagem positiva de si mesmas. Todavia, elas encontram desafios em ajustar suas práticas e seus discursos a uma visão plena de sustentabilidade. Enquanto algumas empresas voltam suas práticas para a questão ambiental, outras direcionam para a questão social, e existem, ainda, aquelas que apontam exclusivamente para a questão econômica (Claro, Claro, \& Amâncio, 2005, 2008).

Para Spence (2007), os relatórios promulgados são entendidos como um veículo por meio do qual as organizações podem se comunicar. Eles compreendem, de forma genérica, o abastecimento de dados auditados ou não, relativos aos eventos e impactos de atividades da organização em relação ao meio 
ambiente. De modo específico, os relatórios abrangem riscos, impactos, políticas, estratégias, custos, despesas, receitas, passivos ou qualquer outra informação pertinente ao seu desempenho ambiental, direcionada a seus stakeholders, possibilitando-lhes conhecer seu relacionamento com a própria organização. Tais comunicações também são proferidas por outros meios, como as revistas e os boletins institucionais, jornais de circulação regional ou nacional, entre outros.

Os chamados Relatórios de Sustentabilidade tendem a ser de caráter público e atender às preocupações das partes interessadas, de exigências legais e pressões internas da cadeia de suprimentos, de pares e da sociedade como um todo. No Brasil, a obrigatoriedade desses relatórios ambientais, segundo Tinoco e Kraemer (2004), limita-se às empresas que possuem elevado potencial de degradação em relação ao meio ambiente.

Para análise documental foram considerados, neste estudo, os Relatórios de Sustentabilidade divulgados e disponibilizados no site da empresa estudada, referentes aos anos de 2007 a 2011, publicados até 2012, como fonte discursiva. Tais documentos puderam reproduzir aspectos da vida social e ambiental da empresa, além de fatores econômicos, bem como os elementos textuais e iconográficos.

Verificamos ainda a construção do discurso da sustentabilidade face as suas dimensões, de acordo com o proposto por Sachs (1992): (a) sustentabilidade social - considera o desenvolvimento em sua multidimensionalidade, abrangendo todo o espectro de necessidades materiais e não materiais; (b) sustentabilidade econômica - permite a alocação e a gestão mais eficientes dos recursos e um fluxo regular do investimento público e privado; avalia a eficiência econômica, sobretudo de maneira macrossocial; (c) sustentabilidade ecológica - o uso de recursos potenciais dos vários ecossistemas, compatível com sua mínima danificação, e de recursos ou produtos renováveis e/ou abundantes e ambientalmente inofensivos, da pesquisa de tecnologias limpas; (d) sustentabilidade espacial configura a relação de equilíbrio entre campo e cidade, perfazendo uma melhor distribuição territorial de assentamentos humanos e atividades econômicas; (e) sustentabilidade cultural - traduz o conceito normativo do ecodesenvolvimento em uma pluralidade de soluções particulares, que respeitem as especificidades de cada ecossistema, de cada cultura e local.

\section{A análise sócio-hermenêutica do discurso}

A interpretação na Análise Sociológica do Discurso ou Análise Sócio-hermenêutica, segundo Alonso e Callejo (1999), apoia-se na questão social e nos espaços comunicativos concretos que se formam e são elaborados nos discursos dos atores como práticas significantes. Conde (2009) ressalta que essa proposta de classificação em níveis (Ortí, 2001) ou dimensões (Alonso, 1998) permite a integração de análise das propostas metodológicas procedentes do conjunto de linhas teóricas de investigação social direcionadas ao discurso.

Para análise e interpretação das fontes discursivas, além da perspectiva de análise dos materiais visuais (Serrano, 2008), seguimos o roteiro proposto por Conde (2009) e corroborado por Serrano (2012a). Na definição do espaço epistêmico-metodológico da Análise Sócio-hermenêutica, diante da diversidade constitutiva de tendências e modelos da análise do discurso, utilizamos, neste artigo, a proposição elaborada por Alonso (1998) e Conde (2009). Eles têm o entendimento da análise do discurso em três níveis ou dimensões básicas, a saber: informacional-quantitativo; estrutural-textual; e socialhermenêutico.

O primeiro nível tem como parâmetro de análise a palavra, a dimensão mais denotativa e manifesta do discurso - a análise de conteúdo é uma das linhas de análise mais conhecidas (Conde, 2009). Para Serrano (2012a), num nível mais básico, procuramos fazer uso do que está manifesto no texto, ignorando, muitas vezes, o que está implícito. A ênfase concentra-se na palavra, fazendo uso de ferramentas de análise - como, por exemplo, a análise de frequência, de correlações - ou focada em temas, utilizando codificações, ordenamento e comparações, por meio de uma análise de conteúdo. No segundo nível, no qual se inclui grande parte da tradição francesa de análise do discurso, os textos são concebidos como o resultado de estruturas formais invariantes e universais (Conde, 2009). Para alcançar 
o nível latente, isto é, o que não está explícito pelos sujeitos, trata-se de verificar, segundo Serrano (2012a), a lógica estrutural existente no texto que proporciona chaves para a interpretação. Nesse segundo nível, localizamos quais são as lógicas que atravessam o discurso, quais são os indícios que se conotam com o que se está falando. Estabelecemos, então, os estilos discursivos, rupturas, ausências, metáforas, símbolos e identificamos as cadeias paradigmáticas - como se fala concretamente e que tipos de palavras falam. Ademais, avançamos na identificação das posições discursivas, que implica a percepção ideológica. Essa etapa possibilitou-nos a identificação das maneiras de falar, das relações de poder, como se relacionam com o objeto de estudo - discurso da sustentabilidade, chamados de atratores semânticos. O último nível - no qual se situa a ASD - visa a uma análise contextual dos argumentos, chamada de sócio-hermenêutica. Nesse nível, o parâmetro de análise é o discurso social, o qual é analisado em contextos sociais. Quanto mais se conhece o contexto, maior a riqueza de compreensão que se pode obter do fenômeno analisado (Conde, 2009). Fizemos, pois, a inserção do texto no contexto. Tornou-se necessário fazer e dar sentido a esses elementos, indícios em um contexto que se fala; um contexto em que se desenvolve tal discurso. Verificamos, neste nível, os discursos como constructos a partir do ponto de vista relacional, desde um ponto ou de outro. Analisamos a partir de que sentido esse discurso foi construído, em que lógica se formou e qual a relação de poder existente. No nível sociohermenêutico, tentamos construir esse sistema de discurso, descrito em mapas discursivos, verificando as relações entre si e as relações que se modificam no tempo e na história.

As representações gráficas aqui assinaladas, portanto, ajudam a visualizar e a ordenar os resultados da análise realizada e a identificar as dimensões mais relevantes das linhas de interpretação e análise. Trata-se de uma análise mais aprofundada e de uma reconstituição do conjunto de discursos que é constituído em situação de interação por meio de suas lógicas discursivas. A finalidade, portanto, foi dar sentido texto a texto e mostrar seu dinamismo, sua possível evolução em curto e longo prazo.

\section{O Discurso da Sustentabilidade numa Empresa do Setor de Energia Elétrica: Construção por meio de Materiais Visuais}

A partir das imagens e das retóricas que as acompanhavam nos relatórios de sustentabilidade, passamos a compreender o discurso como parte da construção teórica da realidade. Buscamos, pois, responder, durante todo o processo investigativo, questões do tipo: Quem fala? De que posição se fala? O que está em jogo? Do que se fala? Como se organiza a fala? (Conde, 2009).

A partir do corpus, buscamos, primeiramente, realizar a leitura, tanto visual quanto textual, da construção do discurso da sustentabilidade nos materiais extraídos do Relatório de Sustentabilidade da empresa. A leitura ordenada a partir de mapas de posicionamento - que ajudam a visualizar o comportamento ou o fluxo de ideias considerando os textos e as imagens, nos relatórios - permitiu criarmos, com uso de imagens, uma ordem lógica por meio dos mapeamentos, os quais foram confrontando-os ano a ano. Essa tarefa foi fundamental para a validação da conjectura pré-analítica do estudo, dando prosseguimento às etapas posteriores de análise e interpretação tanto visual quanto textual. Tal conjectura derivou a partir da teoria, das observações e da experiência dos pesquisadores.

Assim, partimos do princípio de que a conjectura pré-analítica, também chamada por Conde (2009), que nos guiou durante a investigação, foi de que houve uma evolução no discurso institucional ao longo dos anos - a tendência do discurso da empresa seguiu um processo de transformação com o passar dos anos no que tange ao discurso da sustentabilidade. Essa conjectura analítica serviu, pois, de orientação, focalizando nossa percepção, e como norteadora ao longo da interpretação e da análise.

\section{Iniciando a análise dos relatórios de sustentabilidade}

O emissor dos discursos é a empresa estudada, cabendo a ela a elaboração e a divulgação dos relatórios de sustentabilidade. Os receptores dos discursos, por sua vez, compreendem, de maneira geral, os stakeholders. A partir dos aspectos enfocados dos materiais visuais, as imagens dos relatórios 
produzem, no observador, entre outros aspectos: (a) um significado de desempenho econômico eficiente, mediante efeitos fotográficos e de animação; (b) a percepção de um elemento que se destaca - o parque produtivo como sendo o lugar e as relações que se mostram nas imagens; (c) a manifestação das composições em cores diversas, exceto em um ano em que são apresentadas em preto e branco, bem como um enquadramento que chama a atenção para uma relação do empreendimento com a natureza; (d) a percepção de que o manifesto das imagens está agrupado preferencialmente na capacidade produtiva da empresa; (e) um significado simbólico de que as obras (instalações, barragens etc.) estão associadas a uma beleza natural; (f) a ideia de que a presença da empresa nos locais onde ocorrem a geração e a distribuição de energia promovem benefícios, corroborada pelo fato de signos e códigos dentro do texto não revelarem os problemas sociais; (g) a relevância da expansão da capacidade produtiva, observada quando a empresa procura mostrar-se alinhada às dimensões da sustentabilidade; (h) a noção de que os investimentos realizados são necessários para o bem comum de toda uma sociedade; (i) a percepção de que os discursos são hegemônicos e não desvelam as relações complexas implícitas inerentes à realização da atividade econômica em questão.

Dessa maneira, o ano de 2007 é marcante para a empresa por vários fatores, entre os quais destacamos a elaboração, naquele ano, do primeiro relatório anual a partir das diretrizes da Global Reporting Initiative (GRI), padrão mundial em Relatórios de Sustentabilidade. Essa iniciativa atendeu aos anseios de seu grupo controlador e decorreu do entendimento, em sua declaração, da sustentabilidade como sendo uma obrigação. Os representantes da companhia enfatizavam o fato de ela ser uma empresa industrial, em fase de crescimento, declarando que se sentem prontos para crescer. Observa-se, a partir disso, a representação de um empreendimento que se encontrava em expansão ou aumento. Percebemos, visualmente, a preocupação em atribuir maior ênfase a aspectos relacionados à categoria (dimensão) econômica. Notamos a evidenciação da potencialidade de crescimento quantitativo do parque industrial da empresa, não obstante a declaração de estar atendendo os padrões estabelecidos em relação às dimensões ambiental e social.

As imagens do ano de 2007 se mostram, de maneira linear, associadas ao progresso, ao crescimento econômico. É perceptível a ênfase para as redes de transmissão instaladas e obras em processo de edificação, dado que a empresa encontrava-se em um novo ciclo de crescimento naquele período. As novas aquisições e/ou construções estão mais presentes e destacadas no relatório exposto do que a própria natureza e a sua interação social. Nas imagens, não percebemos a interação de fundo, prevalecendo o foco nas instalações. Foram marcantes, no ano de 2007, imagens que representam, por um lado, a capacidade produtiva e, por outro, a transformação do entorno sem a preocupação com o impacto causado na natureza. A empresa apresentou-se como possuidora de tecnologia dita dura, rígida, forte, mais industrial e imponente diante de suas instalações, capaz de atender ao seu potencial operacional com eficiência. Em específico, numa das ilustrações, uma torre de transmissão de energia (instalações) encontra-se em primeiro plano, enquanto que a árvore (natureza) permanece em terceiro plano, no intuito de transparecer uma integração harmoniosa entre a empresa e a natureza. Tais imagens não evidenciaram a visão organizacional em ser, de modo sustentável, a melhor empresa de energia brasileira.

O contexto econômico brasileiro demonstrava-se favorável, pois vivia-se um processo de privatização em diversos setores, entre eles, o setor energético. A construção de novos parques geradores surgia, portanto, como protagonista principal na busca do aumento da produtividade - ampliação do quantitativo físico por meio de construções de usinas hidrelétricas e termelétricas. A capacidade instalada era de 66\%, compostos por hidrelétricas, termelétricas e usinas, chamadas fontes complementares de energia (Tractebel, 2008), o que reforça a ênfase por parte da empresa em destacar elementos relacionados à categoria econômica. $\mathrm{O}$ crescimento econômico é, pois, o elemento destacado pela empresa.

No cenário econômico mundial, até o final do ano de 2007, a década de 2000 foi considerada a mais estável e próspera. A partir do ano de 2008, instalou-se a crise econômica de 2008-2009, colocando em risco a economia mundial. O Brasil, embora apresentando um crescimento considerado médio-baixo em relação aos países emergentes, manteve sua economia relativamente estável. Em tempos de crise, os pronunciamentos dos governantes dirigidos à população incentivavam cada vez mais o consumo. 
No ano de 2008, a empresa enfatizou, novamente, informações relacionadas prioritariamente aos investidores. Aquele ano foi marcado pela sua consolidação no mercado como sendo a maior empresa privada de geração de energia elétrica do Brasil. Sua capacidade própria de geração expandiu-se em $66,4 \%$ em relação ao ano anterior. Continuava, pois, a visão dominante do capital frente ao crescimento econômico, como consta em suas declarações: "Sentimo-nos preparados para enfrentar a crise financeira mundial e dispostos a continuar crescendo" (Tractebel, 2009, p. 4). Nos últimos 10 anos, a empresa se propôs a explorar novas oportunidades e expandir seu parque gerador por todo o país. No que se refere à questão da sustentabilidade, esta declara, em seu relatório de 2008, estar comprometida. Os resultados econômicos foram obtidos com responsabilidade social e ambiental.

Diferente do ano de 2007, as imagens no relatório de 2008 trazem mais luminosidade e textura que convergem para elementos que redundam num tipo de discurso mais comprometido com as categorias social e ambiental, porém prevalecendo a econômica. Ao observar o relatório do ano de 2008 , percebemos a representação de uma empresa em transformação, mas ainda superficial, isto é, a empresa não se aprofundou no aspecto visual em relação às questões ambiental e social. Em comparação ao ano anterior, surgiram imagens mais frequentes da natureza, indo ao encontro da questão central assumida pela companhia: "O foco de nossa atividade pauta-se, assim, no equilíbrio do tripé que nos sustenta: apresentar excelente desempenho econômico, ser socialmente justo e atuar com responsabilidade ambiental" (Tractebel, 2009, p. 3).

As imagens em 2008 conduzem à percepção de que a empresa reconhece a necessidade de utilizar recursos - natural e humano - para desenvolver sua atividade operacional. A empresa fez uso do discurso da sustentabilidade para divulgar suas ações operacionais, bem como para demonstrar sua capacidade de ocupação no mercado. Nesse sentido, é compreensível a preocupação por parte da empresa em externar as boas práticas associadas à sustentabilidade em seus relatórios. No intento de cumprir com as exigências do mercado e, dessa forma, ratificar sua participação no Novo Mercado segmento da BM\&FBOVESPA S. A., a empresa manteve suas declarações anteriores (discurso) sobre a necessidade de ampliar a discussão da sustentabilidade para outras dimensões além da econômica. Isso é admitido pela empresa em seu relatório ao afirmar que "conduz seus negócios em conformidade com as melhores práticas de governança corporativa, comprometida com a prestação de contas e transparência na gestão" (Tractebel, 2009, p. 30).

No ano de 2009, consolida-se o segundo ciclo de expansão da empresa, que se manteve, desde o início das suas atividades, na liderança do setor privado de geração de energia elétrica. Do ponto de vista da própria empresa, essa liderança revela-se como adequada à sua estratégia de avaliação de riscos e oportunidades de mercado (Tractebel, 2010). Em 2009, as imagens mostraram-se muito próximas às ilustradas no ano de 2007, evocando determinantes que se associam à necessidade de aceleração do crescimento energético presente naquele contexto brasileiro. Contudo, diferentemente dos demais anos analisados, todas as imagens foram apresentadas em preto e branco, entremeadas por um tom acinzentado. Essas ilustrações sugerem que cada observador - neste caso, em específico, o leitor do relatório - construa seu modo específico de ver e interpretar a cor no objeto que se apresenta, a partir de uma memória pessoal. A leitura que fazemos das imagens no relatório do ano de 2009 da empresa remete à sua capacidade e à sua competência na produção de energia elétrica, no intuito de fazer bem feita a sua atividade operacional. Todavia, não havia a preocupação visual, aparentemente, com as dimensões sociais e ambientais.

Em 2010, início de uma nova década, a empresa mostrou, em seu relatório (Tractebel, 2011), imagens de aspecto natural, isto é, apresentava certa integração com a natureza, no sentido de mitigar e/ou compensar os impactos ambientais causados pela atividade operacional. A companhia apresentava uma proposta de parceria com o meio ambiente e, consequentemente, com a responsabilidade social, reconhecendo-se como parte integrante da natureza. As ilustrações permitem entender que a empresa proporciona mais impactos positivos do que negativos para a sociedade, conforme constatamos nos estudos ambientais de empreendimentos dessa natureza. As imagens mostram aspectos de recuperação do elemento natural que foi destruído ao longo do tempo. Há uma presença maior de contrastes de cores e luminosidade, com uma intervenção suave da natureza, de maneira integrada, como pode ser observado pela continuidade horizontal entre montanha e instalações. As imagens se apresentaram de 
maneira cíclica, em que a obra (construções, hidrelétricas, barragens etc.) está associada à natureza de modo integrado ao desenvolvimento. A empresa encontrava-se em fase de pleno desenvolvimento e procurou destacar a associação harmoniosa entre aspectos econômicos - intrínsecos a uma atividade empresarial - e questões ambientais e sociais.

Nessa perspectiva, entendemos que a companhia buscou alinhar suas ações aos pressupostos estabelecidos, como missão, visão e valores da organização. Surgem, diferentemente do que acontece nos outros anos, ilustrações de pessoas (funcionários) que retrataram no relatório sua satisfação de fazer parte da empresa que, além dos valores e da visão da empresa, entendemos como uma maneira de homenagear seus empregados - entendidos pela empresa como ativo essencial à manutenção da qualidade e da excelência do negócio. O relatório foi ilustrado com fotos e depoimentos de empregados que relataram seu trabalho, sua percepção sobre ele e suas experiências vivenciadas. Exemplo disso está no depoimento de um funcionário, acompanhado por foto, constante no relatório - acompanhado no relatório da foto deste, sob a forma de narrativa em verso, em que ele declara: "eu vejo [o milagre da energia] e faço parte". Os conteúdos comunicativos retratados nas imagens passaram a celebrar a valorização das pessoas de maneira mais explícita e a mostrar, além disso, o reconhecimento dos próprios empregados sobre seu valor, abreviando, portanto, a quantidade de imagens de obras e instalações.

É perceptível, no relatório de 2010, o domínio de imagens relacionadas à natureza e à forma com que a organização e o homem integram-se a ela. A empresa encontrava-se imbricada com a natureza, a ponto de confundirmos uma com a outra. Essa constatação pode ser verificada numa ilustração em que se observa uma condensação de imagens em que o azul e o amarelo das cores da tubulação de uma de suas usinas e de um tipo de planta da natureza passam a compor uma paisagem que se relaciona harmonicamente. Observamos, pois, a presença de uma empresa preocupada com o uso racional dos recursos naturais, valorizando e respeitando o seu entorno. Entretanto, essa mudança no modo de tratar, em seu relatório, sua relação com o meio ambiente, incita-nos a questionar o que levou a empresa a adotar essa postura de racionalização efetiva de recursos, uma vez que um dos principais problemas enfrentados pela sociedade é a cultura de exploração e apropriação da natureza de maneira desordenada, entendendo que os recursos são infinitos e contribuindo, assim, para um desenvolvimento econômico insustentável.

Preocupada com a maneira pela qual é percebida, em 2011, a empresa "se empenha em ser reconhecida não apenas pela qualidade de suas operações, mas também por princípios fundamentais à conduta das suas atividades, como ética, profissionalismo, respeito ao meio ambiente e às pessoas" (Tractebel, 2012, p. 58). Tonalidades de cores que muitas vezes parecem confundir céu, terra e água, além da luminosidade e do foco empregados, corroboram e ratificam esse posicionamento da empresa. A exemplo de 2010, e ainda de maneira mais enfática, observa-se, no relatório de 2011, a necessidade que a organização tem de ser compreendida e percebida como mais um elemento pertencente à natureza. No relatório, a atividade de produção de energia foi retratada como uma criadora de beleza natural. E, por assim dizer, a presença da empresa no ambiente natural provoca também encantos, além de promover a saúde e o bem-estar de seus colaboradores. Em outras palavras, a empresa resgatou, de maneira harmoniosa, os benefícios proporcionados pela atividade econômica desempenhada.

Depreendemos, também, em relação aos relatórios apresentados pela empresa, a presença de uma transformação na forma de tratar e exibir as informações ao seu público de interesse reconhecido pela empresa (stakeholders), entre eles: (a) empregados e seus representantes; (b) comunidade; (c) imprensa; (d) clientes; (e) fornecedores; (f) governo; (g) acionistas; (h) entidades sociais, ambientais e do setor; (i) instituições financeiras; e (j) empresas do setor. No relatório de 2011 - ao ser comparado com o de 2007 - percebe-se a busca da empresa em evidenciar uma maior aproximação entre ela e os diversos stakeholders, mesmo que enfatizando, em seu discurso textual, informações relacionadas ao mercado e, de certa forma, de interesse de seus investidores.

Um veículo de comunicação, segundo Freitas (2009), pode assumir papel relevante como mecanismo político para moderar a construção simbólica de uma empresa que tem o intuito de se projetar - com imagens, por exemplo. As imagens da organização não só interagem com os empregados 
e a sociedade, legitimando-a, como também "concorrem para criar espaços cênicos no ato de linguagem" (Charaudeau, 1983, p. 39). São, portanto, decorrentes de efeitos da fala e parecem constituir maneiras de pensar a realidade da empresa, bem como sua análise pode contribuir para a consciência dos processos envolvidos na comunicação (Freitas, 2009).

\section{Discurso da sustentabilidade: posições discursivas}

Conde (2009 como citado em Mastella, 2015) compreende como posição discursiva o trabalho equivalente ao responder às perguntas: quem fala? De que posição social fala? Para o autor, a análise das posições discursivas tem que ser produzida sempre a partir do que se expressa no texto e, a partir daí, determinar um lugar social e uma específica rede social de produção do discurso. Sendo assim, o desenho prévio do grupo pode nos ajudar a analisar as posições sociais desde que os interlocutores investigados produzam e elaborem opiniões, argumentações e tomadas de posição.

A análise de posições discursivas está associada às frações constitutivas identificadas que remeteram a uma espécie de orientação geral (Conde, 2009) para realização da análise e construção do discurso da sustentabilidade da Tractebel Energia S. A. Essas posições, segundo Ruiz (2009), podem ser entendidas como "papéis discursivos típicos socialmente definidos (ou questões) que os sujeitos adotam em suas práticas discursivas concretas" (p. 13).

Destarte, a análise das posições discursivas permitiu uma conexão dos discursos concretos com o espaço social no qual têm surgido e, nesse sentido, uma interpretação sociológica do discurso. A leitura ordenada estabelecida durante as tarefas iniciais de análise serviu de caráter provisório para a leitura do corpus - visual ou textual, permitindo estabelecer comparações entre um e outro material analisado e detectar a variabilidade entre eles. Associada à análise das imagens, fizemos a leitura e a análise do texto escrito; em outros termos, consideramos também a retórica que acompanhava as imagens apresentadas no Relatório de Sustentabilidade.

A partir da apresentação e da interpretação dos relatórios apresentadas, incitamos o seguinte questionamento: que tipo de lógica (visual e retórica) surge no discurso da empresa por meio dos Relatórios de Sustentabilidade? Com isso, buscamos reposicionar a empresa em seu discurso (Figura 2), desconsiderando uma análise linear propriamente dita e considerando ser este um estudo qualitativo. Pelo mapeamento, observamos que a empresa tem passado por um processo de amadurecimento e transformação, em que a imagem apresentada nos relatórios referente às instalações e à natureza foi se modificando ao longo dos anos (de 2007 a 2011). Nos últimos, veiculou-se uma imagem de empresa que está preocupada em evidenciar questões ambientais (natureza) e sociais (humana), além dos aspectos econômicos. Não tratamos, neste estudo, de fazer uma análise cartesiana em cima de eixos, mas de representar uma tendência que impossibilita de ser enquadrada por métodos quantitativos, tendo em vista sua natureza subjetiva que parte da interpretação do pesquisador. 
NATUREZA TRANSFORMADA

(reconstruída)

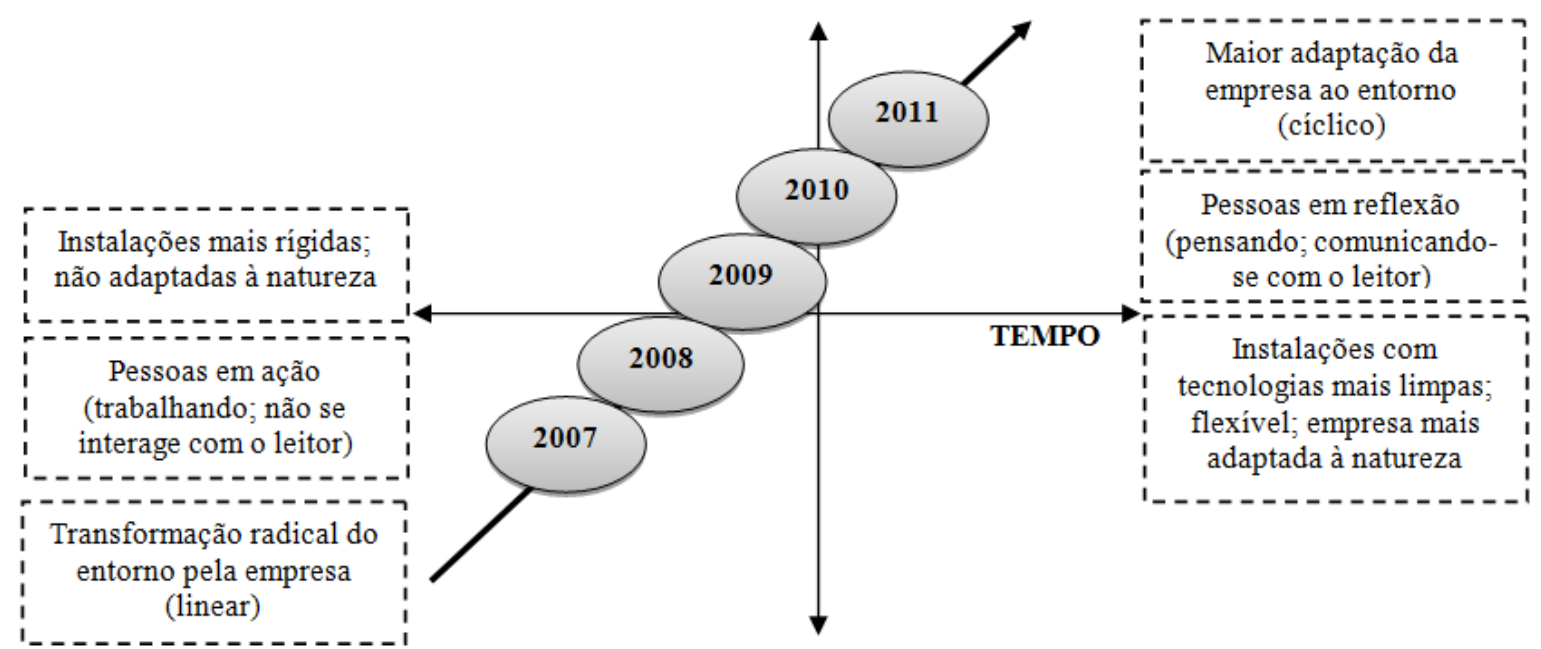

NATUREZA VIRGEM

(intacta)

Figura 2. Discurso Institucional - Relatório de Sustentabilidade, 2007 a 2011

Fonte: Elaborada pelos autores.

A tendência do discurso visual, a princípio, manteve a mesma trajetória do discurso textual, conforme foi evoluindo ao longo dos últimos anos. Pelas imagens que se apresentam nos relatórios, observamos que as instalações (máquina, construção etc.) representam um modelo de transformação e de intervenção na natureza que vai se modificando ao longo dos anos, e que os recursos humanos, em 2011, passam a ter uma presença e uma valorização maiores, com forte interação com o leitor.

\section{Configurações narrativas do discurso da sustentabilidade}

$\mathrm{Na}$ análise de Conde (2009), as configurações narrativas consistem em gerar uma aproximação literal e global do corpo do texto em função dos objetivos da investigação, de forma a produzir as primeiras hipóteses sobre aquelas dimensões, eixos ou vetores multidimensionais dos textos, ou seja, representações gráficas, que cumpram as seguintes condições: existência no texto de coerência e consistência interna à luz da dimensão elegida, e busca de conexão de um sentido geral do texto com um contexto concreto de produção e com os objetivos da investigação. Dentro deste processo de análise, portanto, estão os espaços semânticos (a serem trabalhados no próximo subcapítulo).

As configurações narrativas representaram, neste estudo, uma maneira de descrever o latente expresso no nível manifesto dos textos e das imagens. Elas relacionam-se com a configuração das posições discursivas, podendo ocorrer simultaneamente. Consideramos, nesse procedimento, as tensões, os conflitos, as diferenças de posições e de opiniões expressadas pelos sujeitos discursivos. Essa análise busca, pois, apontar o eixo principal da mensagem manifestada no discurso.

O conteúdo espontâneo de aparição de temáticas centrais da pesquisa durante a análise de relatórios permitiu o progressivo encadeamento dos temas que configuraram a base da ASD do discurso da sustentabilidade. Partindo do eixo principal - que compreende, de um lado, uma natureza virgem (intacta) e, de outro, uma natureza transformada (reconstruída), constatamos que a onda de propagação que representa os interesses econômicos permaneceu imbricada com o discurso da sustentabilidade ao longo dos anos nas diferentes fontes discursivas (Figura 3). 


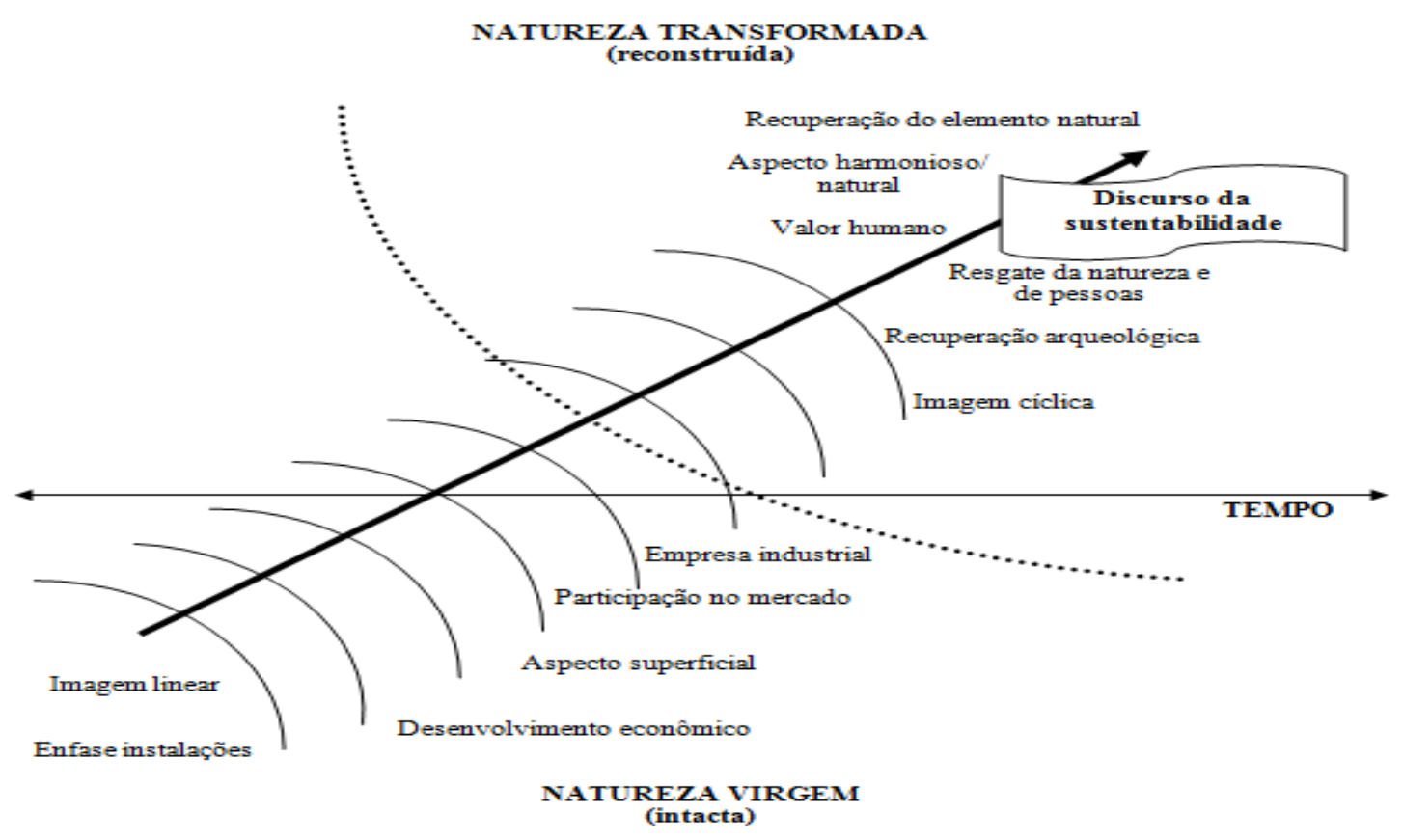

Figura 3. Configuração Narrativa - Relatórios de Sustentabilidade Fonte: Elaborada pelos autores.

A dimensão econômica está associada às demais (ambiental e social). Notamos, com o passar do tempo, a inserção de posicionamentos no âmbito ambiental e social, por parte da empresa, seguindo uma tendência mundial no contexto organizacional. Essa constatação converge com os achados no estudo de Kavinski, Souza-Lima, Maciel-Lima e Floriani (2010).

A dimensão ambiental passa a ser considerada como um condicionante para a lucratividade do empreendimento. Isso não significa que, caso ela não seja observada, a atividade tornar-se-á necessariamente menos lucrativa, mas que a sustentabilidade ambiental passará a constituir um fator econômico que determina a alocação mais eficiente dos recursos.

\section{Espaços semânticos do discurso da sustentabilidade}

Dentro dos processos de análise, estão os espaços semânticos, para os quais a construção consiste em organizar o conjunto de possíveis associações e agrupamentos que estabeleçam entre si diálogos. Para os espaços semânticos, é necessário que sejam possíveis campos de significações compartilhados entre uns e outros, por sua proximidade semântica em relação ao objeto de investigação, ou por qualquer outra razão (Conde, 2009).

Desta forma, os espaços semânticos relacionam-se estreitamente com o conjunto de unidades léxicas, consideradas, a título de conjecturas de trabalho, como dotadas de uma organização estrutural subjacente (Conde, 2009). Todavia, no percurso da Análise Sociológica do Discurso, a vinculação e a possível organização estrutural subjacente se deu desde sua pertinência com o contexto social, pragmático e histórico da investigação em relação ao discurso da sustentabilidade - objeto de estudo. Assim, foi possível configurar e delimitar os principais conteúdos, suas materialidades verbais e suas fronteiras.

Ademais, estendemos a análise e a interpretação ao uso da língua, aos discursos concretos e ao modo como esse discurso se vinculou ou se dissociou das diferentes formas de abordar o discurso da sustentabilidade. Em tal procedimento, levamos em consideração os distintos caminhos narrativos e os segmentos argumentativos e discursivos que se desenvolveram e foram se reconstruindo através dos discursos. 
Na Figura 4, utilizamos o triângulo de Lévi-Strauss, utilizado pelos autores da ASD (Conde, 2009) para estabelecer os espaços semânticos face às dimensões da sustentabilidade, segundo proposto por Sachs (1993).

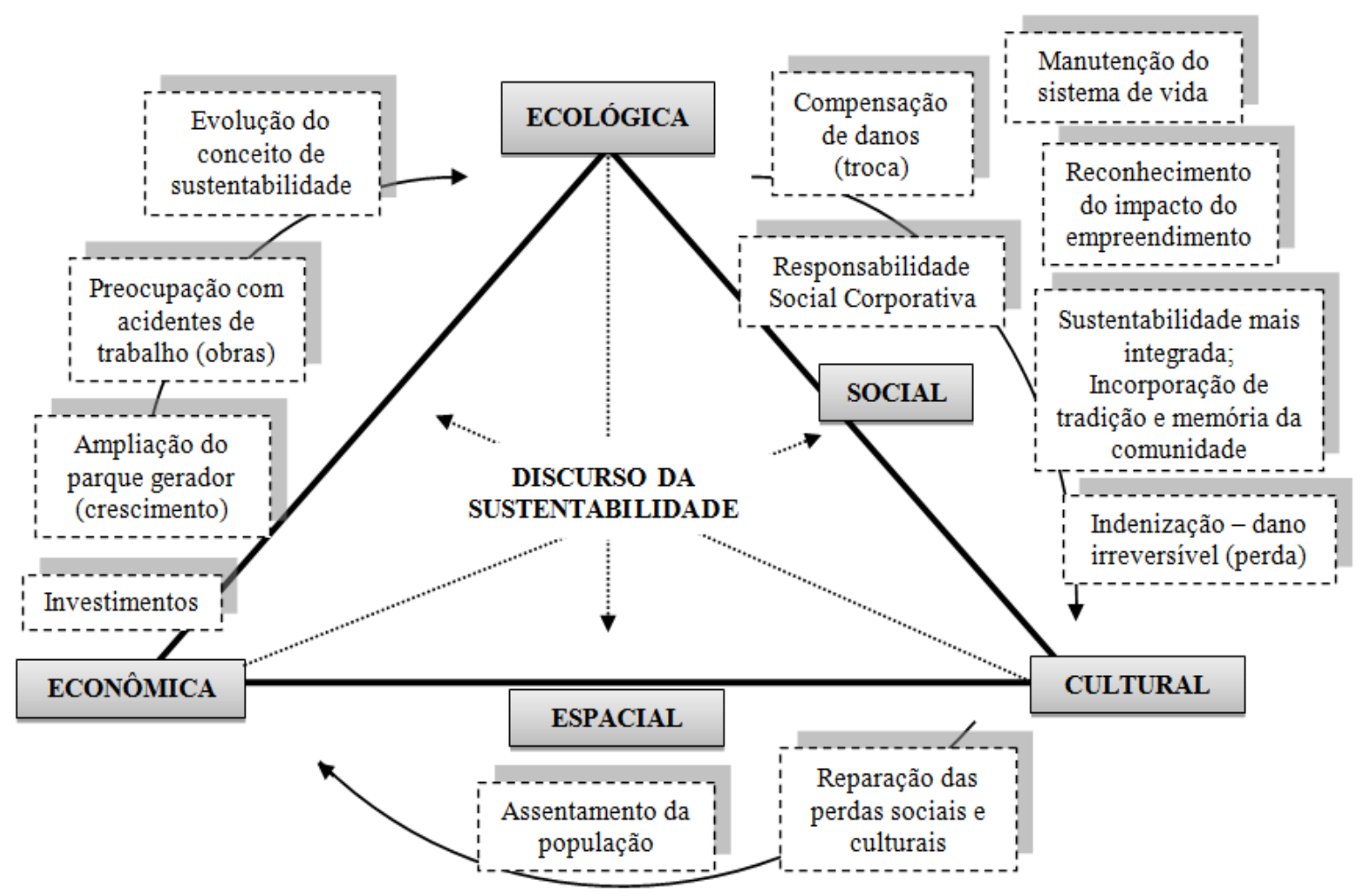

Figura 4. Espaços Semânticos - Fontes Discursivas Face às Dimensões da Sustentabilidade Fonte: Elaborada pelos autores.

O discurso da sustentabilidade é manifestado pela empresa ao enfatizar que sua expansão é obtida com responsabilidade social e ambiental, com uso de energia limpa ou renovável e de tecnologias limpas (Tractebel, 2012), em prol do desenvolvimento sustentável apregoado pelo Estado. O discurso também revela que a empresa realiza suas ações em favor da perspectiva de contribuir para o desenvolvimento sustentável do país, ao utilizar os recursos naturais de maneira sustentável. Há uma tensão junto à sociedade e aos investidores em torno dos impactos ambientais gerados pela atividade operacional desenvolvida pela empresa (sociedade/investidores) e da manutenção da atividade econômica frente à rentabilidade proporcionada (investidores). A sociedade é entendida como beneficiária desse processo. Assim, a empresa manifesta seu discurso em prol da sociedade. $\mathrm{O}$ aumento do fornecimento de energia elétrica se faz necessário para a melhoria da qualidade de vida e bem-estar social, ideia passada pela empresa a fim de legitimar o que faz - produção/geração de energia elétrica.

Em relação aos investidores, a empresa conduz seu discurso no sentido de evidenciar sua capacidade e sua condição de gerar rentabilidade satisfatória nos negócios. No que tange ao contexto econômico, a empresa revela seus projetos expansionistas e de ocupação de mercado e busca atrair investidores. A sustentabilidade é percebida como uma variável propagandística de convencimento dos investidores (Tractebel, n.d.). É predominante no discurso a ênfase à dimensão econômica. Todavia, as demais dimensões são manifestadas como coadjuvantes, de maneira a corroborar com a imagem positiva da empresa, ou seja, proporcionar lucros com responsabilidade. A empresa utiliza o discurso para revelar suas ações em prol do meio ambiente: compensações e indenizações; manutenção do sistema de vida; responsabilidade social; resgate do patrimônio cultural (tradição histórica e memória da comunidade); assentamento da população atingida pelos empreendimentos; entre outras práticas sustentáveis. 


\section{Considerações Finais}

O percurso desenvolvido neste estudo começou por algumas inquietações sobre a complexidade do discurso no contexto organizacional, especificamente no que tange à sustentabilidade. $\mathrm{O}$ discurso da sustentabilidade tornou-se objeto desta pesquisa em razão de estar imiscuído no jargão dos negócios, tornando-se uma palavra de ordem e de uso politicamente correto. Dos estudos teóricos outrora realizados, observamos que o da sustentabilidade vem sendo fragilizado por críticos como um instrumento propagandístico, e, por vezes, falacioso e banalizado, conforme atestam Loose e Peruzzolo (2008).

O grande fato impulsionador do aparecimento da sustentabilidade como estratégia e maneira de retirar das práticas ambientais e sustentáveis o aumento de valor e oportunidades de inovação - seja em nível de processos, seja do desenvolvimento de produtos e serviços, deu-se pela necessidade de cumprimento da legislação (Gomes, 2009). Entretanto, Fonseca (2009, p. 23) alerta que "ter o discurso ambientalista como norma social, passível de gerar lucro ou prejuízo simbólico, possibilita que o fato de dizer 'ambientalmente correto' possa ser uma estratégia de determinados atores sociais", que visam extrair posições social e economicamente vantajosas.

O discurso da sustentabilidade é uma construção carregada de interesses, sejam eles individuais ou coletivos. A construção do discurso da sustentabilidade manifestada neste estudo não fugiu a este pensamento. Uma empresa cuja atividade operacional é considerada de alto impacto ambiental procura mostrar à sociedade que realiza suas ações com responsabilidade e de modo sustentável.

A Análise Sócio-hermenêutica do Discurso, como enfoque metodológico dentro da visão qualitativa, representou, neste estudo, uma metodologia capaz de decompor o discurso, construindo e evidenciando a face que buscamos estudar: a da sustentabilidade. Ademais, a adoção de tal método contribuiu para o fortalecimento da tradição de pesquisas qualitativas no campo organizacional brasileiro. No entanto, como alertam Godoi, Coelho e Serrano (2014), em virtude da inexistência de unanimidade sobre como deve ser praticada a abordagem, existe sobre diversas formas já identificadas na literatura de pseudoanálises, originárias da reduzida formalização da ASD, e que têm gerado conflitos e desentendimentos com a prática da investigação social propriamente dita. As principais pseudoanálises são: (a) pseudoanálise através de síntese - caracterizada pelo resumo de trechos da transcrição de entrevistas, ignorando os detalhes e sutilezas discursivas dos dados originais, que altera e distorce o objeto de análise, antes do processo de interpretação; (b) pseudoanálise baseada na tomada de posição - implica em assumir uma postura de aprovação ou rejeição sobre a postura de quem fornece o discurso; (c) pseudoanálise por excesso ou isolamento de citações - revelada pela ausência de comentários do analista acerca dos dados ou, inversamente, pela tendência da redação referir-se às citações ao invés de analisá-las; (d) pseudoanálise circular dos discursos e dos construtos mentais - acredita que as citações e discursos falam por si e são suficientes para comprovar a expressões de pensamento, ideias, opiniões, atitudes, e até mesmo, a existência de um repertório ou ideologia subjacente; (e) pseudoanálise por falsa generalização - extrapola os dados propriamente ditos, por exemplo, transformar uma determinada característica de alguns participantes em um atributo pertencente a todos os membros da categoria da amostra; (f) pseudoanálise por localização dos elementos - atenta exclusivamente a alguns detalhes das afirmações encontradas no estudo, restringindo-se à localização e esquecendo-se de objetivar o exame de como os dispositivos discursivos são estabelecidos, o que permitiria realizar a dinâmica interacional.

Outra limitação da utilização conjunta do método da Análise Sociológica do Discurso com o Método de Análise de Qualitativa de Material audiovisual talvez possa ter sido o excesso de fontes e de métodos de análise - fator que impediu, por exemplo, o uso completo de todas as etapas da ASD.

Desde o percurso de descoberta até a efetiva construção metodológica, utilizando o discurso da sustentabilidade da empresa como objeto, traçamos, primeiramente a conjectura pré-analítica - que nos guiou incessantemente durante todo o percurso investigativo até os resultados. A interpretação dos estilos discursivos nas fontes escolhidas nos permitiu atingir o último procedimento - denominado análise das posições discursivas, das configurações narrativas e dos espaços semânticos - na construção 
do discurso da sustentabilidade em uma empresa do setor de energia elétrica. Essas inferências foram possíveis a partir das fontes analisadas, principalmente quando a análise de material visual nos incitou a repensar os achados, trazendo um efeito que o texto não reproduz, conectando-nos diretamente com o emocional. Isso nos leva a destacar o principal diferencial em relação à maneira com a qual trabalham os autores de primeira geração da Análise Sociológica do Discurso - Jesús Ibánez, Alfonso Ortí, entre outros - e os de segunda geração - representados principalmente por Fernando Conde. Outro destaque, a partir da construção do método, foi a oportunidade de aproximação entre autores tradicionais e as técnicas desenvolvidas na Espanha por autores de terceira geração - Araceli Serrano e Ángel Gordo -, que desenvolveram a metodologia de análise de imagens aqui utilizada.

\section{Referências}

Alonso, L. E. (1998). La mirada cualitativa en sociología. Madrid: Fundamentos.

Alonso, L. E., \& Callejo, J. (1999). El análisis del discurso: del postmodernismo a las razones prácticas. Revista Española de Investigaciones Sociológicas, (88), 37-74.

Bohnsack, R. (2008). The interpretation of pictures and the documentary method. Forum: Qualitative Social Research, 9(3), art. 26, Retrieved from http://nbn-resolving.de/urn:nbn:de:0114fqs0803267

Charaudeau, P. (1983). Langage et discours: éléments de sémiolinguistique. Paris: Hachette.

Claro, P. B., Claro, D. P., \& Amâncio, R. (2005, setembro). Entendemos sustentabilidade em sua plenitude? Análise de fatores que influenciam a interpretação do conceito. Anais do Encontro Nacional da Associação Nacional de Pós-Graduação e Pesquisa em Administração, Rio de Janeiro, RJ, Brasil, 28.

Claro, P. B., Claro, D. P., \& Amâncio, R. (2008). Entendendo o conceito de sustentabilidade nas organizações. Revista de Administração, 43(4), 289-300.

Conde, F. (2009). Análisis sociológico del sistema de discursos (Colección Cuadernos Metodológicos $\mathrm{N}^{\mathrm{o}} 43$ ). Madrid: Centro de Investigaciones Sociológicas.

Conde, F., \& Camas, V. (2001). Paseando por los dibujos sobre la salud: una experiencia de trabajo de los escolares madrileños. Madrid: Consejería de Sanidad de la Comunidad de Madrid.

Correa, N. (2008). El "ritmo" de la ciudad y los movimientos espaciales, un ejercicio de análisis visual. In A. J. Gordo \& A. Serrano (Coords.), Estrategias y prácticas cualitativas de investigación social (pp. 287-305). Madrid: Pearson Prentice Hall.

Fonseca, I. F. da (2009). Entre o discurso e a prática: boa governança e Agenda 21 locais na Amazônia (Dissertação de mestrado). Centro de Desenvolvimento Sustentável, Universidade de Brasília, Brasília, DF, Brasil.

Freitas, E. C. (2009). O discurso na comunicação organizacional: uma abordagem semiolingüística na inter-relação linguagem e trabalho. Intercom - Revista Brasileira de Ciências da Comunicação, 32(1), 189-208. doi: 10.1590/S1809-58442012000200020

García-Vera, A. B., \& Maillo, H. M. V. (2011). Antropología audiovisual: medios e investigación en educación. Madrid: Trotta.

Godoi, C. K., Coelho, A. L. A. L., \& Serrano, A. (2014). Elementos epistemológicos e metodológicos da análise sociológica do discurso: abrindo possibilidades para os estudos organizacionais. Organização \&Sociedade, 21(70), 509-536. doi: 10.1590/S1984-92302014000300009 
Gomes, S. C. J. de (2009). As práticas de sustentabilidade estratégica nas empresas portuguesas estudo de caso: Corticeira Amorim (Dissertação de mestrado). Faculdade de Economia da Universidade do Porto, Porto, Portugal.

Gordo, A. J., \& Serrano, A. (2008). Estrategias y prácticas cualitativas de investigación social. Madrid: Pearson Prentice Hall.

Halliday, T. L. (2009). Discurso organizacional: uma abordagem retórica. In M. K. Kumsch (Org.), Comunicação organizacional (Vol. 2, pp. 31-52). São Paulo: Saraiva.

Iasbeck, L. C. A. (2007). Imagem e reputação na gestão da identidade organizacional. Organicom, 7(2), 84-97. doi: 10.1590/1809-5844201516

Iasbeck, L. C. A. (2009). Identidade organizacional e a construção dos discursos institucionais. In M. Kunsch (Org.), Comunicação organizacional (pp. 7-30). São Paulo: Saraiva.

Ibáñez, J. (1979). Más allá de la sociología. El grupo de discusión: técnica y crítica. Madrid: Siglo XXI.

Ibáñez, J. (1985). Del algoritmo al sujeto. Perspectivas de la investigación social. Madrid: Siglo XXI.

Kavinski, H., Souza-Lima, J. E., Maciel-Lima, S. M., \& Floriani, D. (2010). La apropiación del discurso de la sustentabilidad por las organizaciones empresariales brasileñas. Cultura y representaciones sociales, 4(8), 34-69.

Lei $n .^{\circ}$ 10.165, de 27 de dezembro de 2000. (2000). Altera a Lei n. 6.938, de 31 de agosto de 1981, que dispõe sobre a Política Nacional do Meio Ambiente. Diário Oficial da União. Brasília, DF: Casa Civil.

Loose, E. B., \& Peruzzolo, A. C. (2008, setembro). Como o meio ambiente é tematizado no discurso jornalístico da Folha de S. Paulo. Anais do Congresso Brasileiro de Ciências da Comunicação, Natal, RN, Brasil, 31.

Luna Hernández, J. R. (2009). Foto-etnografía llevada a cabo por personas en situación de pobreza en la frontera norte de México. Forum: Qualitative Social Research, 10(2), art. 35. Recuperado de http://www.qualitative-research.net/index.php/fqs/rt/printerFriendly/1310/2786. doi: $10.1177 / 1468794110385885$

Mastella, A. S. (2015). O discurso feminino sobre o consumo de produtos estéticos: um olhar pósmoderno (Tese de doutorado). Programa de Pós-Graduação em Administração, Universidade do Vale do Itajaí, Biguaçu, SC, Brasil.

Mirzoeff, N. (2003). Una introducción a la cultura visual. Buenos Aires: Paidós.

Morch, R. B., Correia, A. B., Leite, A. L. S., Bueno, C. R., \& Cogan, S. (2009). A estratégia de mercado das geradoras hidrelétricas: uma análise à luz da teoria das restrições. Revista Eletrônica de Gestão Organizacional, 7(3), 331-347. Recuperado de http://www.revista.ufpe.br/gestaoorg/index.php/gestao/article/viewFile/31/28

Ortí, A. (2001). En el margen del centro: la formación de la perspectiva sociológica crítica de la generalización de 1956. Revista Española de Sociología, 1, 119-164.

Peinado, A. (2002). La investigación cualitativa en España: de la vida política al maltrato del sentido. Revista Española de Salud Pública, 76(5), 381-393. doi: 10.4321/S1135-57272015000200004

Persichetti, S. (1997). Imagens da fotografia brasileira (Vol. 1, 2a ed.). São Paulo: Senac.

Rose, G. (2012). Visual methodologies: an introduction to the interpretation of visual materials (3rd). London: Sage. 
Ruiz, J. R. (2009). Análisis sociológico del discurso: métodos y lógicas. Forum Qualitative Sozialforschung/Forum: Qualitative Social Research, 10(2), art. 26. Recuperado de http://digital.csic.es/bitstream/10261/64955/1/Art\%C3\%ADculo\%20FQS\%20\%28espa\%C3\%B 1ol\%29.pdf

Sachs, I. (1992). Transition strategies for the 21st century. Nature and Resources, 28(1), 4-17.

Sachs, I. (1993). Estratégias de transição para o século XXI: desenvolvimento e meio ambiente. São Paulo: Studio Nobel: Fundação do desenvolvimento administrativo.

Schnaith, N. (1998, Mayo). Los códigos de la percepción, del saber y de la representación en una cultura visual. Revista Tipográfica, (4), 1-8.

Serrano, A. (2008). El análisis de materiales visuales en la investigación social: el caso de la publicidad. In A. J. Gordo \& A. Serrano (Coords.), Estrategias y prácticas cualitativas de investigación social (pp. 245-286). Madrid: Pearson Prentice Hall.

Serrano, A. (2012a). Esquema de modalidades de análisis [Apostila: Cultura material y metodologías audiovisuales, Máster en Metodología de la Investigación en Ciencias Sociales: Innovaciones y Aplicaciones]. Madrid: UCM.

Serrano, A. (2012b). Perspectivas de análisis de las imágenes [Apostila: Cultura material y metodologías audiovisuales, Máster en Metodología de la Investigación en Ciencias Sociales: Innovaciones y Aplicaciones]. Madrid: UCM.

Serrano, A., \& Zurdo, A. (2012). Investigación social con materiales visuales. In M. Arroyo Menéndez \& I. Sábada Rodríguez (Coords.), Metodología de la investigación social: técnicas innovadoras y sus aplicaciones (pp. 217-250). Madrid: Síntesis.

Spence, C. (2007). Social and environmental reporting and hegemonic discourse. Accounting, Auditing and Accountability Journal, 20(6), 855-882. doi: 10.1108/09513570710830272

Tinoco, J. E. P., \& Kraemer, M. E. P. (2004). Contabilidade e gestão ambiental. São Paulo: Atlas.

Tractebel Energia. (2008). Relatório anual de sustentabilidade 2007: um novo ciclo de crescimento. Recuperado de http://www.tractebelenergia.com.br/wps/wcm/connect/f8fa3dd3-c8c2-40f4b2d3-

0036d370a682/Relat\%C3\%B3rio_de_Sustentabilidade_2007.pdf?MOD=AJPERES\&CACHEI $\mathrm{D}=\mathrm{f} 8 \mathrm{fa} 3 \mathrm{dd} 3-\mathrm{c} 8 \mathrm{c} 2-40 \mathrm{f} 4-\mathrm{b} 2 \mathrm{~d} 3-0036 \mathrm{~d} 370 \mathrm{a} 682$

Tractebel Energia. (2009). Relatório anual de sustentabilidade 2008. Recuperado de http://www.tractebelenergia.com.br/wps/wcm/connect/aafadd84-df38-4e89-baf0a593bd22de30/95092.pdf?MOD=AJPERES\&CACHEID=aafadd84-df38-4e89-baf0a593bd22de30

Tractebel Energia. (2010). Relatório de sustentabilidade 2009. Recuperado http://www.tractebelenergia.com.br/wps/wcm/connect/90e63320-2ab3-4ebf-a801-

62a064111c7b/Rel_Anual_2009_29_06_PTG_new.pdf?MOD=AJPERES\&CACHEID=90e633 20-2ab3-4ebf-a801-62a064111c7b

Tractebel Energia. (2011). A arte de renovar está em nossas mãos. Relatório de sustentabilidade 2010. Recuperado de http://www.tractebelenergia.com.br/wps/wcm/connect/0050c7d2-27a6-4adca58eaaf4cbb7753e/Tractebel_RS2010_PT_multimidia_2.pdf?MOD=AJPERES\&CACHEID=0050c 7d2-27a6-4adc-a58e-aaf4cbb7753e

Tractebel Energia. (2012). Energia, movimento, mudança. Relatório de sustentabilidade 2011. Recuperado de http://www.tractebelenergia.com.br/wps/wcm/connect/b794dfed-a64c-44a9- 
8eee-a63a992c2993/135819.pdf?MOD=AJPERES\&CACHEID=b794dfed-a64c-44a9-8eeea63a992c2993

Tractebel Energia. (n.d.). Relatórios de sustentabilidade. Recuperado de http://www.tractebelenergia.com.br/wps/portal/internet/a-companhia/relatorios-desustentabilidade

Valle Gastaminza, F. del (2001). El análisis documental de la fotografía. Recuperado de http://pendientedemigracion.ucm.es/info/multidoc/prof/fvalle/artfot.htm

\section{Dados dos Autores}

Ana Lúcia de Araújo Lima Coelho

Cidade Universitária, 58051-900, João Pessoa, PB, Brasil. E-mail: alalcoelho@gmail.com

Christiane Kleinübing Godoi

Rua Joao Coan, 400, Centro, 88337-300, Biguaçu, SC, Brasil. E-mail: chriskg@ univali.br

Christiano Coelho

Cidade Universitária, 58051-900, João Pessoa, PB, Brasil. E-mail: floripacoelho@ gmail.com 